\title{
Optimasi Ekstraksi Pati Jagung Madura-3 Berdasarkan Lama Perendaman dan Konsentrasi $\mathrm{NaOH}$
}

\author{
Mojiono ${ }^{1 *}$, Diana Nurus Sholehah ${ }^{2)}$ \\ 1,2) Universitas Trunojoyo Madura \\ 1)mojiono@trunojoyo.ac.id, ${ }^{2)}$ diananurus@yahoo.co.id \\ DOI: https://doi.org/10.21107/rekayasa.v13i2.6429
}

\section{Extraction of Madura-3 corn starch by optimizing soaking time and $\mathrm{NaOH}$ concentration}

\begin{abstract}
Corn production in Madura showed a tremendous contribution to total production in Province of East Java. Noticeably, the province was recorded to yield 6 million tons of corn, responsible for approximately 31.3\% of domestic production in 2018, as reported by BPS-Statistics. For this reason, there is a need for developing technology that enables to convert the corn into other valuable products, such as starch. Corn starch is essential material since it is applied in copious sectors mainly including food and pharmacy. This present work aimed at optimizing conditions for isolating starch of Madura-3 corn carried out using d-optimal design in Response Surface Methodology (RSM). The variables included soaking time (X1) and concentration of $\mathrm{NaOH}$ (X2), arranged as follows: X1 (12 - 36 h) and X2 (0.05-0.5\%) according to preliminary research. The results demonstrated that the model constructed from data was significant, resulting in $\mathrm{F}$ value of 7.30 and Prob $>\mathrm{F}$ of $0.0075(\mathrm{P}<0.05)$. Furthermore, the statistical analysis showed lack of fit at 0.45 , which means that it was insignificance, which is favorable for this experiment. In addition, adequate precision of the constructed model was achieved at $7.469(>4.0)$. Based on statistical evaluation, the optimum condition for starch isolation was found at X1 $=36 \mathrm{~h}$ and X2 $=0.05 \%$, which was predicted to yield starch at $5.29 \%$ with desirability value of 0.719 .
\end{abstract}

Keyword: Madura-3, corn starch, optimization, RSM

\begin{abstract}
ABSTRAK
Produksi jagung di Madura memberikan andil besar terhadap total produksi jagung di Jawa Timur. Di tingkat nasional, BPS menunjukkan bahwa produksi jagung di Jawa Timur mencapai 6 juta ton, berkontribusi sebesar 31.3\%, atau hampir sepertiga dari total produksi jagung nasional. Produksi jagung yang besar seharusnya didukung dengan kesiapan teknologi produksi untuk mengolahnya menjadi aneka produk turunan, seperti pati. Pati jagung adalah bahan strategis karena digunakan di berbagai sektor, khususnya pangan. Studi ini dilakukan untuk optimasi proses ekstraksi pati jagung Madura-3. Teknik optimasi dilakukan menggunakan desain rancangan d-optimal pada Response Surface Methodology (RSM). Kondisi optimasi meliputi lama perendaman (X1) dan konsentrasi NaOH (X2), dengan rentang sebagai berikut: X1 (12 jam - 36 jam) dan X2 (0.05-0.5\%). Hasil uji statistik memperlihatkan bahwa model yang berhasil dikonstruksi dinyatakan signifikan, ditunjukkan dengan F value sebesar 7.30, dan Prob $>$ F sebesar $0.0075(\mathrm{P}<0.05)$. Selain itu, lack of fit adalah 0.45 , memperlihatkan bahwa parameter ini tidak signifikan. Lack of fit yang tidak signifikan memang diinginkan. Selain itu, nilai adequate precision dari model mencapai 7.469 (diinginkan $>4.0$ ) Hasil optimasi menunjukkan bahwa kondisi optimum dapat dicapai pada kondisi X1 = 36 jam dan $\mathrm{X} 2=0.05 \%$. Kondisi optimum ini diprediksi mampu menghasilkan nilai rendemen $5.29 \%$, dengan nilai desirability 0.719 .
\end{abstract}

Kata Kunci: jagung Madura-3, optimasi ekstraksi, RSM

\section{PENDAHULUAN}

Produksi jagung di Madura berkontribusi signifikan terhadap total produksi jagung di Jawa Timur. Di tingkat nasional, produksi jagung di Jawa Timur mencapai 6 juta ton, berkontribusi sebesar $31.3 \%$, atau hampir sepertiga dari total produksi jagung nasional (Badan Pusat Statistik, 2018). Sementara itu, produksi jagung dari 4 kabupaten di Madura pada tahun 2016

\section{Article History:}

Received: January, 14 $4^{\text {st }}$ 2020; Accepted: May, $10^{\text {th }} 2020$

REKAYASA ISSN: 2502-5325 has been Accredited by Ristekdikti (Arjuna) Decree: No. 23/E/KPT/2019 August $8^{\text {th }}$, 2019 effective until 2023 mencapai hampir 700 ribu ton, atau setara dengan $11.14 \%$ total produksi jagung di Jawa Timur. Di Madura, daerah penghasil jagung tertinggi adalah Sumenep (339.183 ton), kemudian Bangkalan (144.771 ton), Pamekasan (135.987 ton), dan Sampang (79.165) (Badan Pusat Statistik, 2018). Dengan demikian, jagung di Madura merupakan komoditas yang sangat penting untuk memenuhi kebutuhan industri baik pangan maupun non pangan.

\section{Cite this as:}

Mojiono, M., \& Sholehah, D.N. (2020). Optimasi Ekstraksi Pati Jagung Madura-3 Berdasarkan Lama Perendaman dan Konsentrasi $\mathrm{NaOH}$. Rekayasa, 13(2), 118-124. doi: https://doi.org/10.21107/rekayasa.v13i2.6429 
Masyarakat Madura memang mengenal jagung sebagai salah satu sumber karbohidrat utama selain beras dan singkong. Untuk tujuan ketahanan pangan, diversifikasi pangan berbahan olahan jagung dapat dilakukan. Sebelum mengenal jagung unggul hibrida, jagung lokal Madura seringkali ditanam oleh petani. Beberapa jagung lokal Madura antara lain Tambin, Kretek, Talango, Guluk-guluk, dan Manding. Penampilan kultivar jagung Madura (Tambin, Kretek, Talango, Guluk-Guluk, Manding) sebelumnya telah diteliti oleh (Amzeri, 2009). Upaya riset oleh tim peneliti dari Universitas Trunojoyo Madura juga dilakukan melalui eksplorasi jagung lokal Madura di seluruh Pulau Madura, untuk mendapatkan tetua yang akan dijadikan sebagai varietas unggul Madura. Salah satu varietas unggul yang telah diluncurkan adalah Madura-3. Keunggulan utama varietas Madura-3 adalah produksivitas yang tinggi, mencapai 6-7 ton per hektar. Dengan demikian, produksi jagung ini dapat diandalkan dalam upaya ketahanan pangan.

Jagung baik dalam bentuk tepung dan pati telah digunakan secara luas untuk produk pangan, antara lain mi jagung (Muhandri et al., 2011). Karbohidrat merupakan komponen kimia utama pada jagung, sehingga jagung kerap digunakan sebagai bahan utama suatu pangan. Selain itu, dari sisi pohon industri, jagung menjadi sumber pangan pokok di daerah tertentu, makanan penyela (jagung rebus dan bakar), makanan ringan (brondong, tortilla), tepung, kue dan roti. Kegunaan lain, jagung bisa menjadi bahan baku untuk industri sirup, dekstrin, dan pati (Maflahah, 2010). Selain itu, pati jagung juga menjadi bahan yang sangat potensial untuk pengembangan bioplastik (Jabeen et al., 2015).

Pati sendiri merupakan komponen penyusun utama pada tepung, sehingga sangat menentukan mutu produk akhir. Tiap pati memiliki ciri khas yang perlu dipelajari agar dapat digunakan secara tepat sebagai bahan baku (Li et al., 2020). Jagung adalah salah satu sumber pati (starch) melimpah, sebagai cadangan karbohidrat berbentuk granula kecil dengan ukuran $2 \mu \mathrm{m}-30 \mu \mathrm{m}$ dan bentuk polyhedral dan spherical. Pati bisa diisolasi dari jagung dan digunakan untuk beragam industri pangan meliputi bakeri, sup, konfeksioneri, dan pasta (Paraginski et al., 2014), bahkan saat ini digunakan sebagai eksipien farmasi (Odeku, 2013). Sementara itu, Angellier et al. (2006) menggunakan pati jagung untuk bahan penguat (reinforcing agent) pada pembuatan nanokristal pati. Dengan demikian, pati jagung dianggap sebagai biopolimer multiguna (versatile biopolymer) yang unggul dan dapat diaplikasikan untuk industri pangan, nonpangan, hingga farmasi. Selain itu, pati juga adalah polimer yang relatif mudah diperolah dan dapat diekstraksi dengan biaya terjangkau (Przetaczek-Rożnowska, 2017).

Kendati Tantangan utama ekstraksi pati adalah persentase rendemen yang relatif rendah. Suarni et al. (2013) melaporkan hasil ekstraksi pati dari 11 varietas jagung di Indonesia dengan rendemen terendah $28.95 \%$ (varietas Palakka) dan tertinggi 39.96\% (varietas Srikandi putih -1). Sementara itu, Maflahah (2010) menghasilkan rendemen pati jagung sebesar $19.33 \%$, dengan pendekatan neraca massa. Paraginski et al. (2014) melaporkan rendemen pati jagung yang lebih tinggi, yaitu berkisar $45.99 \%$ hingga $66.94 \%$. Variasi rendemen pati hasil ekstraksi bisa sangat bervariasi, sesuai dengan jenis dan kondisi ekstraksi. Berdasarkan paparan ini, maka optimasi metode ekstraksi pati dari jagung Madura-3 perlu dilakukan untuk menghasilkan rendemen terbaik, berdasarkan kondisi ekstraksi yaitu lama perendaman dan konsentrasi $\mathrm{NaOH}$.

\section{METODE PENELITIAN}

\section{Bahan}

Jagung Madura-3 diperoleh dari PT. Giri Raya Agro. Bahan kimia untuk ekstraksi dan analisis menggunakan jenis analytical grade, antara lain akuades, natrium metabisulfit, dan $\mathrm{NaOH}$.

\section{Isolasi pati}

Proses ekstraksi pati dilakukan dengan metode basah, diadopsi dari metode Suarni, Firmansyah, and Aqil (2013). Metode ekstraksi ini kemudian akan dikembangkan sebagai dasar modifikasi metode yang optimum. Pertama, sortasi dilakukan untuk memilih biji jagung yang utuh. Sebanyak $500 \mathrm{~g}$ biji jagung direndam dengan larutan Na-bisulfit 0.2\% (1000 ml) selama 12-36 
jam, sesuai kondisi perlakuan. Selanjutnya, biji hasil perendaman dimasukkan ke blender elektrik (Waring Laboratory Blender), ditambahkan akuades $500 \mathrm{ml}$, dan digiling pada kecepatan rendah selama 5 menit. Sebanyak $3000 \mathrm{ml}$ akuades ditambahkan untuk proses ekstraksi pati, kemudian disaring menggunakan kain kasa. Berikutnya, proses separasi dilakukan dengan cara sentrifugasi untuk mengendapkan fraksi pati, sehingga pati basah dapat dipisahkan dari fraksi cairan. Untuk memisahkan pati dengan protein, $\mathrm{NaOH}$ ditambahkan pada rentang $0.05-0.5 \%$, diaduk, kemudian dipisahkan menggunakan sentrifugasi (diulagi tiga kali pencucian) pada kecepatan 3000 rpm selama 10 menit. Endapan pati dikeringkan menggunakan oven (Memmert) pada suhu $50^{\circ} \mathrm{C}$ selama 12 jam, kemudian dihaluskan serta diayak menggunakan ayakan (80 mesh).

\section{Rancangan Percobaan}

\section{Riset pendahuluan}

Riset pendahuluan untuk menentukan batas dan bawah variabel bebas, yaitu lama perendaman (X1) dan konsentrasi $\mathrm{NaOH}$ (X2). Berdasarkan serangkaian eksperimen awal, ditetapkan batas atas dan bawah untuk masing-masing variabel adalah X1: 12 - 36 jam dan X2: $0.05-0.5 \%$.

\section{Studi optimasi}

Rancangan penelitian untuk optimasi menggunakan d-optimal design dari RSM untuk dengan bantuan perangkat lunak Design Expert $7.0{ }^{\circledR}(D X-7$ trial version) dari Stat Ease. Kombinasi perlakuan yang terdiri atas lama perendaman (X1) dan konsentrasi $\mathrm{NaOH}(X 2)$. Respon penelitian berupa rendemen (maksimum). Respon memiliki persamaan atau model matematika yang menunjukkan pengaruh variabel terhadap respon. Kriteria utama yang digunakan untuk evaluasi persamaan yang dipakai dalam optimasi yaitu signifikansi model $(p<0.05)$, lack of fit $(p>0.05)$ pada taraf signifikansi $5 \%$. Selain itu, model harus mempunyai nilai adequate precision di atas 4 .

Kombinasi kondisi proses optimal ditentukan berdasarkan nilai keinginan (desirability) yang paling mendekati 1.0 melalui tahap optimasi. Tahap optimasi terdiri dari dua komponen yaitu penentuan tujuan (goal) dan skala prioritas. Tujuan (maximize) respon ditetapkan. Selain itu, tiap respon memiliki skala prioritas yang ditunjukkan dengan nilai importance mulai dari 1 (+) sampai $5(+++++)$.

\section{Perhitungan rendemen}

Perhitungan rendemen dilakukan berdasarkan Palacios-Fonseca et al. (2013), dan disajikan dalam bentuk \% rendemen, yaitu:

$$
\% \text { rendemen }=\frac{\text { berat kering pati setelah ekstraksi }}{\text { berat kering jagung }} \times 100 \%
$$

\section{HASIL DAN PEMBAHASAN}

\section{Hasil}

Isolasi pati menggunakan metode alkali (basa). Secara ringkas, dokumentasi proses ekstraksi pati jagung Madura-3 dapat dilihat pada Gambar 1. Adapun studi optimasi yang dilakukan bertujuan untuk menemukan kondisi optimum. Kondisi optimasi meliputi lama perendaman (X1) dan konsentrasi $\mathrm{NaOH}$ (X2). Rentang dua variabel ini sudah ditentukan berdasarkan hasil eksperimen pendahuluan, sebagai berikut: X1 (12 jam - 36 jam) dan X2 (0.05 - 0.5). Rentang nilai tersebut kemudian dimasukkan ke software

Tabel 1. Kombinasi perlakuan $\mathrm{X} 1$ dan $\mathrm{X} 2$ serta rendemen $(Y)$

\begin{tabular}{llll}
\hline No & NaOH (\% $\begin{array}{l}\text { Lama } \\
\text { Perendaman } \\
\text { (jam) }\end{array}$ & $\begin{array}{l}\text { Rendemen } \\
\text { (\%) }\end{array}$ \\
\hline 1 & 0,19 & 12 & 3,09 \\
2 & 0,5 & 12 & 1,49 \\
3 & 0,06 & 12 & 1,92 \\
4 & 0,5 & 12 & 0,77 \\
5 & 0,06 & 12 & 3,29 \\
6 & 0,35 & 15 & 4,38 \\
7 & 0,05 & 18,97 & 3,28 \\
8 & 0,5 & 22,67 & 1,58 \\
9 & 0,5 & 22,67 & 2,51 \\
10 & 0,31 & 25,5 & 2,57 \\
11 & 0,15 & 27 & 3,14 \\
12 & 0,28 & 36 & 5,12 \\
13 & 0,05 & 36 & 3,48 \\
14 & 0,05 & 36 & 7,80 \\
15 & 0,5 & 36 & 3,95 \\
16 & 0,5 & 36 & 3,25 \\
\hline
\end{tabular}




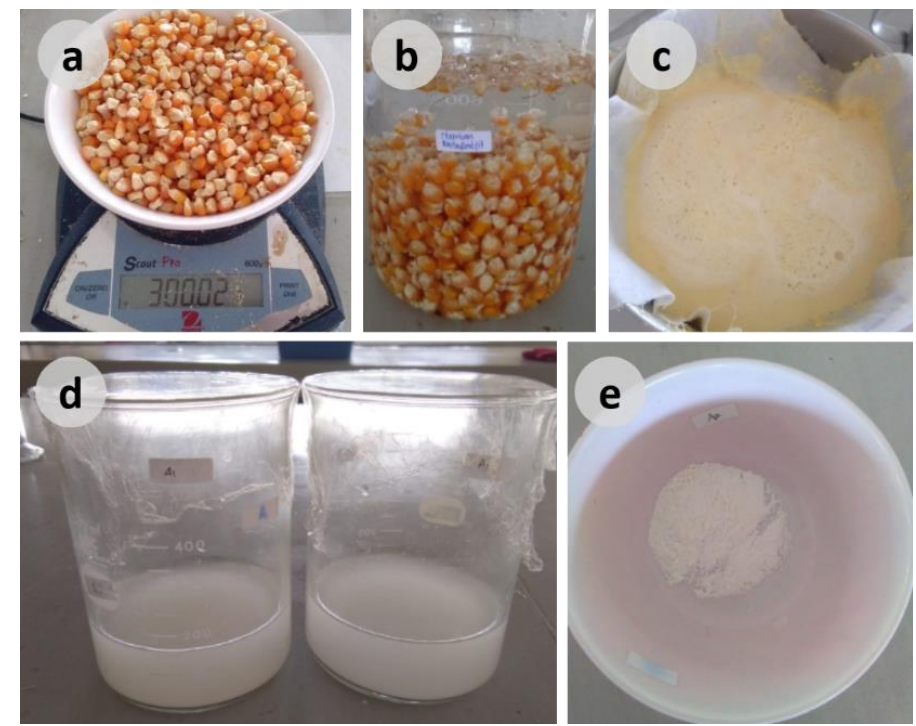

Gambar 1 Ringkasan proses ekstraksi pati jagung Madura-3. Penimbangan bahan (a), perendaman (b), penghancuran (c), pengendapan (d), dan (e) pati hasil ekstraksi

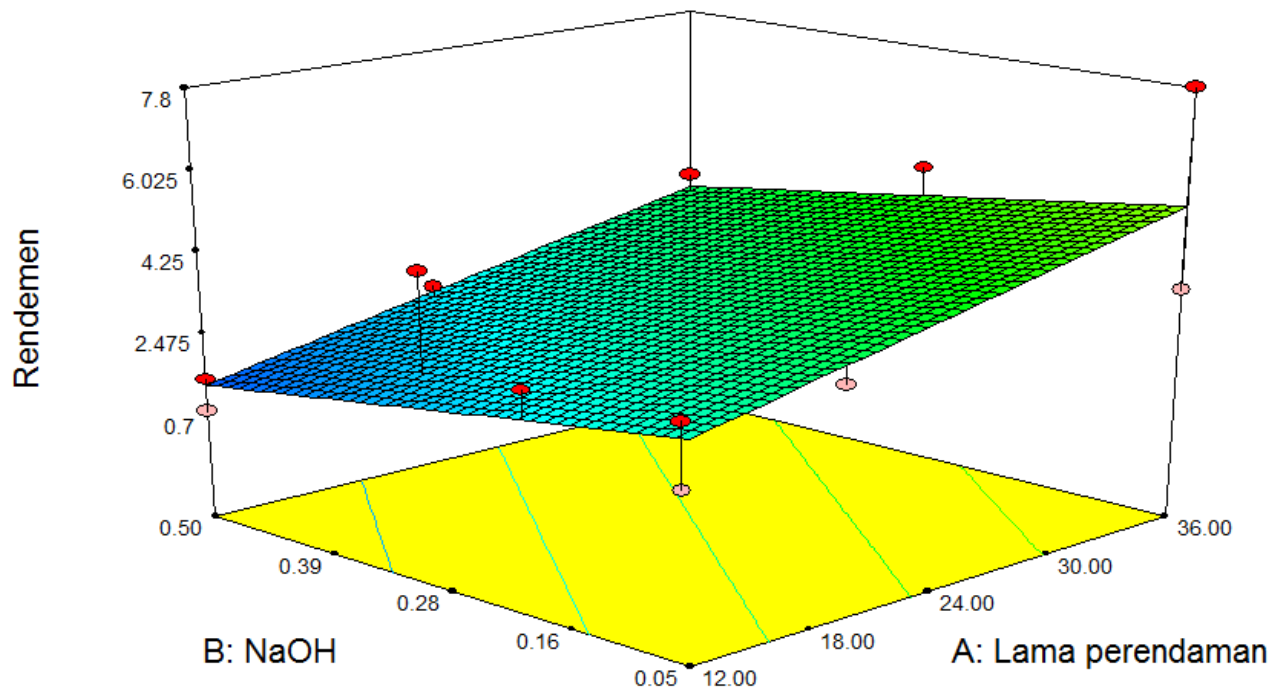

Gambar 2. Surface plot pengaruh konsentrasi $\mathrm{NaOH}$ dan lama perendaman terhadap rendemen.

Design Expert, dengan rancangan D-optimum. Hasilnya, software merekomendasikan 16 kombinasi perlakuan. Seluruh perlakuan ini kemudian dikerjakan dan direkap hasilnya sehingga diperoleh data lengkap seperti pada Tabel 1.

Data pada Tabel 1 ini kemudian diolah secara statistik di software Design Expert X7. Hasil analisis statistik disajikan pada Tabel 2. Hasil uji statistik memperlihatkan bahwa model yang berhasil dikonstruksi dinyatakan signifikan, ditunjukkan dengan $F$ value sebesar 7.30 , dan Prob > F sebesar $0.0075(P<0.05)$. Selain itu, lack of fit adalah 0.45 , memperlihatkan bahwa parameter ini tidak signifikan. Lack of fit yang tidak signifikan memang diinginkan. Selain itu, nilai adequate precision dari model mencapai 7.469 (diinginkan >4.0).

Berdasarkan evaluais secara statistik, model yang direkomendasikan adalah linear, yaitu:

$$
\text { Rendemen }=2.011+0.096 \mathrm{X}_{1}-3.611 \mathrm{X}_{2}
$$

Berdasarkan persamaan tersebut, lama perendaman tampak memberikan kontribusi positif terhadap rendemen, sedangkan konsentrasi $\mathrm{NaOH}$ berkontribusi negatif. Pengaruh $\mathrm{X} 1$ dan $\mathrm{X} 2$ terhadap rendemen juga dapat divisualisasi melalui tampilan surface plot, seperti pada Gambar 2. Pada surface plot, 
Tabel 2. Hasil analisis statistik ANOVA

\begin{tabular}{lcccccc}
\hline \multicolumn{1}{c}{ Source } & Sum of square & df & Mean square & F value & $\begin{array}{c}\text { p-value } \\
\text { Prob }>\text { F }\end{array}$ & Note \\
\hline Model & 21,62 & 2 & 10,81 & 7,3 & 0,0075 & Significant \\
Lama perendaman & 14,38 & 1 & 14,38 & 9,71 & 0,0082 & \\
$\mathrm{NaOH}$ & 7,56 & 1 & 7,56 & 5,1 & 0,0417 & \\
Residual & 19,25 & 13 & 1,48 & & & \\
Lack of fit & 8,04 & 8 & 1,01 & 0,45 & 0,85 & Not significant \\
Pure Error & 11,21 & 5 & 2,24 & & & \\
\hline
\end{tabular}

diketahui bahwa nilai rendemen akan lebih tinggi pada meningkatnya lama perendaman dan semakin kecil konsentrasi $\mathrm{NaOH}$.

Setelah model ditetapkan, langkah berikutnya adalah penentuan perlakuan optimum. Pada tahapan ini, tiap kriteria (lama perendaman, konsentrasi $\mathrm{NaOH}$, dan rendemen) memiliki goal berbeda-beda dengan opsi sebagai berikut: maximize, minimize, target, in range, dan equal to. Untuk kriteria lama perendaman, pilihan in range ditetapkan sebagai goal. Namun, kriteria konsentrasi $\mathrm{NaOH}$ diinginkan agar bernilai rendah, sehingga fungsi minimize dipilih sebagai goal. Untuk kriteria rendemen, pilihan maximum digunakan agar menghasilkan nilai tertinggi. Semakin tinggi rendemen, maka semakin baik.

Berdasarkan tahapan optimasi, terdapat dua saran kondisi optimum, yaitu (1) X1 36 jam dan X2 NaOH 0.05\%, dan (2) X1 35.02 dan X2 0.05\%. Untuk menentukan pilihan, opsi 1 ditetapkan sebagai kondisi optimum berdasarkan nilai desirability ( $D$-value) yang lebih tinggi. Opsi pertama memperlihatkan nilai desirability 0.719 , sedikit lebih tinggi dari pada opsi kedua dengan nilai desirability 0.708 . Maka, opsi pertama dipilih karena memiliki $D$-value yang lebih tinggi. Kondisi optimum ini diprediksi mampu menghasilkan nilai rendemen $5.29 \%$.

\section{Pembahasan}

Pati merupakan bentuk karbohidrat yang dapat ditemukan di banyak tanaman dan tersusun atas dua fraksi utama, yaitu amilosa dan amilopektin. Amilosa merupakan rantai linear glukosa yang dihubungkan dengan ikatan $\alpha-(1,4)$, sedangkan amilopektin terdiri dari rantai yang sama, namun terdapat cabang pada $\alpha-(1,6) \quad$ D-glukosa
(Hoover, 2001). Karena bersumber dari banyak tanaman, pati mempunyai variasi karakteristik yang sangat tinggi, antara lain ukuran granula, rasio amilosa dan amilopektin. Perbedaanperbedaan inilah yang juga menyebabkan profil gelatinisasi pati bisa berbeda. Profil gelatinisasi pati diukur menggunakan RVA, sehingga perilakunya dapat diamati seiring dengan perubahan suhu dan waktu. Perbedaan ini juga memberikan efek yang tidak sama saat diaplikasikan pada produk pangan. Gelatinisasi pati bergantung pada banyak faktor, antara lain kadar air, laju pemanasan, sumber pati, proses pengolahan, dan rasio amilopektin/amilosa (Altay and Gunasekaran, 2006). Karakteristik pati juga memberikan dampak signifikan terhadap mutu produk akhir yang dihasilkan, antara lain ukuran granula yang berkorelasi dengan stabilitas adonan (dough), jumlah amilosa yang berkorelasi positif terhadap ketahanan tensil (tensile resistance) pada adonan, serta kristalinitas pati yang berkorelasi negatif terhadap absorpsi air (Li et al., 2020).

Secara umum, metode yang diinginkan dalam ekstraksi pati jagung adalah yang mampu menghasilkan rendemen tinggi. Perendaman biji jagung sebelum penggilingan dimaksudkan untuk melunakkan tekstur luar biji, sehingga pati lebih mudah untuk diekstrak. Penelitian ini memperlihatkan bahwa durasi perendaman yang optimum adalah 36 jam. Hanya saja, perendaman melebihi 36 jam akan merusak biji, karena bahan tersebut mulai terfermentasi, tanda awal dimulainya proses pembusukan. Meski informasi mengenain efek lama perendaman terhadap rendemen pati jagung belum tersedia secara luas, eksperimen serupa untuk pembuatan tepung jagung pernah dilakukan oleh Akbar and Yunianta (2014). 
Hasilnya, perlakuan terbaik diperoleh pada lama perendaman 36 jam dan lama fermentasi 12 jam dengan karakteristik tepung jagung sebagai berikut: rendemen $78.29 \%$, amilosa $24.03 \%$, dan kadar pati $72.17 \%$.

Selain perendaman, penggunaan alkali, misal $\mathrm{NaOH}$, dapat digunakan untuk meningkatkan kualitas pati yang dihasilkan. Umumnya, teknik alkali ini dimanfaatkan untuk tujuan penghilangan protein (deproteinization). Cardoso et al. (2007) mengekstrak pati beras BRIRGA 110 dengan tambahan perlakuan $\mathrm{NaOH}$ pada berbagai konsentrasi $0.06 \%-0.30 \%(\mathrm{w} / \mathrm{v})$; efisiensi proses deproteinasi dievaluasi menggunakan teknik fluorescence spectroscopy. Hasil analisis membuktikan bahwa $\mathrm{NaOH}$ mampu mereduksi keberadaan protein pada sampel, ditunjukkan dengan besaran total luas area puncak (peak). Hanya saja, peningkatan konsentrasi $\mathrm{NaOH}$ yang digunakan, tidak semerta-merta selalu berdampak positif pada kualitas pati. Secara mikrostruktur, tampak terjadi perubahan formasi granula yang signifikan akibat perbedaan konsentrasi $\mathrm{NaOH}$. Proses eliminasi protein dengan bantuan secara alkali menggunakan $\mathrm{NaOH}$ di atas $0.24 \%$ justru menghasilkan degradasi granula pati (Cardoso et al., 2007), seperti yang juga ditemukan oleh Cardoso et al. (2006).

Kondisi alkali serta kondisi ekstraksi lainnya juga bisa berdampak pada profil gelatinisasi pati. Dokić et al. (2010) melakukan investigasi terhadap karakteristik pati yang diekstrak menggunakan faktor berikut: konsentrasi $\mathrm{NaOH}$ (0.15\% dan $0.30 \%$ ), waktu pengadukan (30 menit dan 90 menit) serta suhu $\left(25^{\circ} \mathrm{C}\right.$ dan $\left.50{ }^{\circ} \mathrm{C}\right)$. Karakterisktik pati hasil ekstraksi kemudian dibandingkan dengan wet-milled corn starch. Hasilnya, pati dari ekstraksi alkali memiliki suhu gelatinisasi yang lebih rendah, namun viskositasnya lebih tinggi dibandingkan pati wetmilled. Riset tersebut juga menyimpulkan bahwa semakin tinggi konsentrasi alkali menyebabkan semakin rendah nilai viskositas puncak, serta menghasilkan gel pati yang lebih kuat. Hal ini menandakan adanya degradasi granula pati dipicu oleh kondisi alkali, sehingga mempercepat keluarnya amilosa dari granula, serta memicu terbentuknya ikatan hidrogen lebih intensif selama fase gelasi.
Eksperimen ini adalah tahapan awal untuk menemukan kombinasi perlakuan optimum. Teknik optimasi banyak diperlukan untuk menyelesaikan permasalahan dalam suatu proses produksi. Metode permukaan respon (Response Surface Methodology - RSM) tampaknya menjadi metode paling populer yang digunakan di dalam proses optimasi. RSM merupakan kumpulan teknik statistika dan matematika yang berguna menganalisis permasalahan tentang beberapa variabel bebas yang memengaruhi variabel tidak bebas atau respon, serta bertujuan untuk mengoptimumkan respon tersebut. Dengan demikian, RSM dapat dipilih untuk mencapai dua tujuan sekaligus, yakni: (1) mendapatkan fungsi pendekatan yang cocok untuk meramalkan respon yang akan datang, serta (2) menentukan nilai-nilai dari variabel bebas yang mampu menghasilkan respon yang optimum.

\section{KESIMPULAN DAN SARAN}

Kondisi optimasi meliputi lama perendaman (X1) dan konsentrasi $\mathrm{NaOH}\left(X_{2}\right)$, dengan rentang sebagai berikut: X1 (12 jam - 36 jam) dan X2 (0.05-0.5\%). Hasil uji statistik memperlihatkan bahwa model yang berhasil dikonstruksi dinyatakan signifikan, ditunjukkan dengan $F$ value sebesar 7.30, dan Prob > F sebesar 0.0075 $(\mathrm{P}<0.05)$. Selain itu, lack of fit adalah 0.45 , memperlihatkan bahwa parameter ini tidak signifikan. Lack of fit yang tidak signifikan memang diinginkan. Selain itu, nilai adequate precision dari model mencapai 7.469 (diinginkan >4.0). Hasil optimasi menunjukkan bahwa kondisi optimum dapat dicapai pada kondisi X1 $=36$ jam dan $\mathrm{X} 2=0.05 \%$. Untuk riset berikutnya mengenai pati jagung Madura-3, faktor yang dilibatkan dalam ekstraksi dapat dikembangkan, dilanjutkan dengan karakterisasi gel serta sifat reologinya.

\section{DAFTAR PUSTAKA}

Akbar, M. R., \& Yunianta, Y. (2014). Pengaruh lama perendaman $\mathrm{Na} 2 \mathrm{~S} 2 \mathrm{O} 5$ dan fermentasi ragi tape terhadap sifat fisik kimia tepung jagung. Jurnal Pangan Dan Agroindustri, 2(2), 91-102. 
Altay, F., \& Gunasekaran, S. (2006). Influence of drying temperature, water content, and heating rate on gelatinization of corn starches. J. Agric. Food Chem, 54, 42354245.

Amzeri, A. (2009). Penampilan lima kultivar jagung Madura. Agrovigor, 2(1), 23-30.

Badan Pusat Statistik. (2018). Produksi jagung menurut provinsi. https://www.bps.go.id/linkTableDinamis /view/id/868

Cardoso, M. B., Putaux, J. L., Samios, D., \& da Silveira, N. P. (2007). Influence of alkali concentration on the deproteinization and/or gelatinization of rice starch. Carbohydrate Polymers, 70(2), 160-165. https://doi.org/10.1016/j.carbpol.2007.0 3.014

Cardoso, M. B., Samios, D., \& Silveira, N. P. (2006). Study of protein detection and ultrastructure of brazilian rice starch during alkaline extraction. Starch/Staerke, 58(7), 345-352. https://doi.org/10.1002/star.200600495

Dokić, L., Dapčević, T., Krstonošić, V., Dokić, P., \& Hadnadev, M. (2010). Rheological characterization of corn starch isolated by alkali method. Food Hydrocolloids, 24(2-3), 172-177. https://doi.org/10.1016/j.foodhyd.2009. 09.002

Hoover, R. (2001). Composition , molecular structure, and physicochemical properties of tuber and root starches: a review. Carbohydrate Polymers, 45, 253267.

Jabeen, N., Majid, I., \& Nayik, G. A. (2015). Bioplastics and food packaging: A review. Cogent Food \& Agriculture, 1(1), 1117749. https://doi.org/10.1080/23311932.2015. 1117749

Li, Y., Liu, H., Wang, Y., Shabani, K. I., Qin, X., \& Liu, X. (2020). Comparison of structural features of reconstituted doughs affected by starches from different cereals and other botanical sources. Journal of Cereal Science, 93, 102937. https://doi.org/10.1016/j.jcs.2020.10293 7
Maflahah, I. (2010). Analisis Proses Pembuatan Pati Jagung ( Maizena ). Embryo, 7(1), 40-45.

Muhandri, T., Ahza, A. B., Syarief, R., \& Sutrisno. (2011). Optimasi proses ekstrusi mi jagung dengan metode permukaan respon. Jurnal Teknologi Dan Industri Pangan, XXII(2), 97-104.

Odeku, O. A. (2013). Potentials of tropical starches as pharmaceutical excipients: A review. Starch/Starke, 65, 89-106. https://doi.org/10.1002/star.201200076

Palacios-Fonseca, A. ., Castro-Rosas, J., GomezAldapa, C. ., Tovar-Benitez, T., MillanMalo, B. ., del Real, A., \& RodriguezGarcia, M. . (2013). Effect of the alkaline and acid treatments on the physicochemical properties of corn starch. Cyta - Journal of Food, 11(S1), 67-74.

https://doi.org/10.1080/19476337.2012. 761651

Paraginski, T. R., Vanier, N. L., Moomand, K., de Oliveira, M., Zavareze, E., Silva, R. M., Ferreira, C. D., \& Elias, M. C. (2014). Characteristics of starch isolated from maize as a function of grain storage temperature. Carbohydrate Polymers, 102,

88-94. https://doi.org/10.1016/j.carbpol.2013.1 1.019

Przetaczek-Rożnowska,

I.

(2017). Physicochemical properties of starches isolated from pumpkin compared with potato and corn starches. International Journal of Biological Macromolecules, 101, 536-542. https://doi.org/10.1016/j.ijbiomac.2017. 03.092

Suarni, S., Firmansyah, I. U., \& Aqil, M. (2013). Keragaman mutu pati beberapa varietas jagung. Penelitian Pertanian Tanaman Pangan, 32(1), 50-56. 